pastoral in English) consistently approaches labour from a medieval perspective, the latter's focus on the otium of the Arcadian tradition is conflicted, undermined by its depictions of the dark side of a labour-free countryside beset by the violence of brigandage and slavery. This "new" pastoral, symbolized by Spenser's Pastorella-a product of the court rather than the country-is a mode not only liberated from the countryside but perhaps its greatest threat.

Overall, Little offers readers a lucid and nuanced revisionist reading of the early modern pastoral's inseparability from the medieval tradition of writing rural labour that preceded it, thereby illuminating the social, political, and religious roots of a mode whose interests are often understood as primarily classist. The early chapters of Little's study eloquently set the stage for the insightful close readings of Spenser that follow, and her command of the material throughout is admirable. Although the author's engagement with early modern pastoral is somewhat limited, the real power of Transforming Work is generated by its elaborating a historical continuity for the pastoral, thereby deepening our critical comprehension of the various pressures that shaped and haunt a late medieval tradition's early modern transformations.

MARK ALBERT JOHNSTON

University of Windsor

\title{
Moxey, Keith.
}

Visual Time: The Image in History.

Durham, NC: Duke University Press, 2013. Pp. xiii, $207+28$ ill. ISBN 9788223-5369-0 (paperback) \$24.95.

In his Visual Time: The Image in History, Keith Moxey offers a series of short essays that, broadly speaking, explore the relationship of art historiography to the question of time. Divided into two parts, the book brings together Moxey's considerations over the last ten years or so of two important trends in recent art historiography that call into question certain received approaches to both the art object and how it is positioned in history. More specifically, the first half of the book is devoted to explorations of heterochrony as a possible antidote to the ultimately Eurocentric understanding of time that has governed art history since its inception as a discipline in the nineteenth century. The second 
half of the book turns to the anachronic nature of aesthetic experience and how renewed focus on the aesthetic character of the art work offers a salutary corrective to contextual approaches that tend to suppress, even deaden (3), the very thing that governs our attention as art historians in the first place: that is, the unique power of the art object to affect the present.

Though the issue of time is, as Moxey notes, the hinge "that unites the two axes around which the book is organized" (8), in the context of art historiography Moxey's intentional focus on these two chronicities makes for a striking juxtaposition since it brings into one conversation two traditionally opposing approaches in the history of Western art historiography. On the one hand, the notion of heterochrony offers a poststructuralist's alternative to the temporally universalizing grand narrative of the West's progress towards modernity. On the other hand, the idea of the anachronic reintroduces in positive terms a familiar target of the poststructuralists, the "ideology of the aesthetic."

In the seven chapters that constitute the book, the respective concerns of each of these two approaches to art historical time are never very far from view despite Moxey's division of the book into two parts. Part 1 is as much about how we might positively embrace the "protean" effects of the image-as we combat the monochronism of the Modernist narrative-as it is about the segregating effects of the old aestheticism that established that narrative. Similarly, part 2 deals with the contextuality of aesthetic response in shaping narratives even while championing the aesthetic capacity of art works "to create their own time for attentive beholders" (175). Thus, it is no surprise that the themes that get raised and treated in the various chapters of the book are the proper children of precisely this kind of bi-lateral reflection, themes like periodization or the problem of contemporaneity which necessarily cause us to revisit, as Moxey admits, the persistent questions in art historiography (8) around the demands of "both historical and aesthetic time" (175).

But if Moxey finds himself looking again at such themes, it is not without the benefit of new modes by which to approach them. As he outlines in his acknowledgments, the content of the book is the result of his own growing awareness over a number of years of both the "provincialism of [art history's] Eurocentric bias" and "the burgeoning importance of ideas of agency or 'presence' in the literature of art history and visual studies" (xii). As offering the greater challenge to his own poststructuralist leanings (The Practice of Theory: Poststructuralism, Cultural Politics, and Art History), the latter set of ideas 
receives the greater emphasis. Indeed, in chapter 1 of part 2, he offers a concise but rich historiography of "the introduction of issues of presence" (54) that in the end sets the semiotic and contextual approach taken in Anglo-American scholarship against the phenomenologically-minded work of the FrancoGerman theorists. The latter's emphasis on the continuing perceptual impact of the art object and its interface with the viewer is the insight he especially wishes to confront and apply to his own scholarship. As a consequence, the book's various chapters essentially document Moxey's multi-year and very hands-on engagement with the issues of time raised by both postcolonial perspectives and the reality of the ongoing effect of the artwork.

Chapter 1, for example, investigates the notion of multiple modernities in the hope of exposing how only a major reconception of our chronological understanding of time would allow us to properly account for works of art produced outside the dominant centres of art production. The second chapter considers the implications of a more art focused approach to the problem of Renaissance periodization while "Contemporaneity's Heterosynchronicity" "continues the discussion of periodization" by scrutinizing the concept of contemporaneity (6).

Following his account of the concept of "presence" in the first chapter of part 2, Moxey turns his attention to specific paintings. Chapter 4 investigates the benefits of approaching the work of Pieter Bruegel "from the perspective of the ontological presence of the image" (6) rather than from the vantage point of iconological interpretation. Similarly, Hans Holbein's The Ambassadors (1533) becomes the focus of chapter 6, "Mimesis and Iconoclasm," alongside an analysis of the "hyperrealistic" contemporary photographs of Thomas Durand. As with his analysis of Bruegel, Moxey's approach to these two paintings focuses especially, in terms reminiscent of Deleuze, on the role of the paintings' surfaces in the manufacture of the illusionistic "presence" they are so well known for. Finally, the last chapter of the volume investigates the historiography of Albrecht Dürer and Matthias Grünewald in an effort to demonstrate the "distancing" that occurs when aesthetic response to an image is suppressed in favour of supposed commitments to historical accuracy and objectivity.

In conclusion, if Moxey's chapters reveal recurring themes that are the natural progeny of reflection on the points of intersection between historical and aesthetic time, then Moxey proves to be the archetypal Socratic midwife in his method of delivering those themes. Never intending, as he says, to offer 
even "tentative answers to the issues confronting the history of art today" (8), he moves the discussion forward by a steady stream of eloquently presented questions aimed at revealing what he considers to be a real, if finally elusive, truth, namely the truth of understanding "the images of cultures other than our own" (175). While the approach certainly suits the complexity of such a truth, it also leaves one longing at times for more definitive answers. "Presencing," for example, is a no less slippery concept than the aesthetic for the myriad ways in which artworks might succeed in "breaking time." Along similar lines, more precise discussion of the signifying capacities of image seems especially warranted. Still, there is something keenly and compellingly appropriate about facing the aporia of art's chronicities through the poetry of Moxey's own evocative writing.

REBEKAH SMICK

Institute for Christian Studies in the Toronto School of Theology

\section{Novoa, James W. Nelson.}

\section{Being the Nação in the Eternal City.}

Portuguese Studies Review Monograph Series 2. Toronto: Baywolf Press, 2014. Pp. 354 +16 ill. ISBN 978-0-921437-52-9 (paperback) \$56.95.

Novoa's important book reconstructs and interprets the lives and deeds of seven Portuguese New Christians who came to prominence in Rome between 1532 and 1588. More than a century ago, Alexandre Hercolano acknowledged the existence of a community of Portuguese conversos in search of papal support against Portugal's Inquisition. However, the names, motivations, and political and commercial strategies, not to mention the social affiliations and artistic taste of these expats, remained almost completely unknown. It is the great merit of Novoa's study not only to have unearthed the history of the naçao from the archives of Rome, Florence, Parma, and Lisboa, but also to have linked it with the broader histories of early modern Portugal, Spain, Italy, the Ottoman Empire, and the Jewish diaspora at large.

The volume comprises an introduction, nine chapters, and a brief conclusion, followed by a documentary appendix, a glossary, and a bibliography. The introduction and the first three chapters lay out the context in which these 